\title{
Russia's Foreign Policy Activities in the Context of Western Sanctions
}

\author{
V.V. Moiseev \\ Belgorod State Technological University named after V.G. \\ Shukhov \\ Belgorod, 308012, Russia \\ din_prof@mail.ru
}

\section{T.S. Bolkhovitina}

Russian Presidential Academy of National Economy and

Public Administration

Bryansk, Russia

info@bfrane.brk.ru

\author{
V. V. Ogneva \\ Russian Presidential Academy of National Economy \\ and Public Administration \\ Orel and Bryansk, Russia \\ ognevavv@yandex.ru.
}

A. S. Sidorov

Russian Presidential Academy of National Economy and Public Administration

Krasnodar, Russia richard0007@bk.ru

\begin{abstract}
It is obvious that today Russia is facing increasing external challenges. They are largely connected with the costs of globalization, the intensification of the confrontational policies of the West, first of all, the USA towards Russia, China, Venezuela and a number of other states. The situation is complicated by the rise of anti-Russian sanctions initiated by the United States of America after the annexation of the Crimea to Russia. At the same time, there is a devaluation of the role of the World Trade Organization, as a whole, of international law in solving major intergovernmental problems, a decline in the prestige of international institutions that are called upon to regulate international relations and ensure a stable world order.

The article notes the importance of implementing the foreign policy function of the Russian constitution, based on the recognition of generally accepted norms of international law respect for the sovereignty, territorial integrity of states, noninterference in the internal affairs of other countries. Analyzes the institutional aspects of Russia's foreign policy. The features of modern world development associated with the struggle for the formation of a new world order are revealed. The author substantiates that Russia's foreign policy priorities are connected with the formation of a multipolar world, the expansion of integration interactions, the strengthening of cooperation with the countries of the Eurasian space and the CIS, and the solution of problems of domestic geopolitics. It is concluded that a dynamically changing world, its challenges and threats suggest the adequacy of measures to strengthen the constitutional security of the state.
\end{abstract}

Keywords-foreign policy; world order; national interests; western sanctions

\section{INTRODUCTION}

Foreign policy and foreign policy activities are concepts that are inextricably linked with the concept of "state", the fundamental principles of which in this area are laid down in the Basic Law of the country. In art, 15 (Clause 4) clearly articulated a clause stating that the generally accepted principles and norms of international law and international treaties of the Russian Federation are part of the legal system of Russia.

The president, in accordance with article 86 of the Basic Law, has the right to direct Russia's foreign policy. The State Duma is responsible for passing laws affecting the sphere of international relations of the Russian Federation. The powers of the Council of the Federation (Article 106) apply to the ratification and denunciation of international treaties of the Russian Federation; determination of the status and protection of the state border of the Russian Federation; issues of war and peace; resolving the issue of the possibility of using the Armed Forces of the Russian Federation outside the territory of the Russian Federation (Article 102). Government on the basis of art. 114 of the Constitution carries out measures to ensure the defense of the country, state security, the implementation of the foreign policy of the Russian Federation [1].

The Russian Constitution establishes that the Russian Federation is in charge of foreign policy and international relations, international treaties; issues of war and peace; foreign economic relations (Art. 71). The joint jurisdiction of the Russian Federation and its subjects is the coordination of international and foreign economic relations of the constituent entities of the Russian Federation and the implementation of international treaties of Russia (Art.72).

The Constitution recognizes the right of the Russian Federation to participate in interstate associations and to transfer to them part of its authority in accordance with international treaties (Article 79), defining the conditions for this participation, namely if it does not entail restricting the rights and freedoms of a person and citizen and does not contradict the foundations of the constitutional order Russian Federation.

Constitutional norms in the sphere of Russian foreign policy are specified in foreign policy concepts and doctrines the Foreign Policy Concept of the Russian Federation [2], the National Security Strategy of the Russian Federation [3], the 
Military Doctrine of the Russian Federation [4], the Maritime Doctrine of the Russian Federation [5], the Information Security Doctrine of the Russian Federation [6].

Thus, the foreign policy function of the constitution is the basis of the foreign policy of the Russian state, which determines the principles of its implementation and the nature of relations with the world community. This function increases with the development of integration processes in the modern world, the norms of international law, and the desire of the subjects of international relations to achieve a fair world order.

Important institutions for the implementation of Russian foreign policy are the Ministry of Foreign Affairs (MFA) and the Security Council, a constitutional advisory body that prepares decisions of the President of the Russian Federation on issues of ensuring internal and external security of the state, as well as on international cooperation in ensuring state security [7].

\section{PROBLEM Statement}

At the beginning of the 20th century, the world was multipolar. As a result of the Second World War and a multitude of local conflicts, a bipolar model emerged with the opposition of two poles - the USSR and the USA. The end of the "cold war" in connection with the collapse of the USSR led to a unipolar system of international relations, with the United States playing the leading role.

The course towards unipolarity was laid down in the US National Strategy 2015, where in the section entitled "Comprehensive Military Strategy" among the "enduring" interests "fixed" rules-based international order provided by the US " [8]. This was preceded, not without the support of big politicians, by the discussion in scientific circles about the present day principles of the Versailles system of international relations, established after the end of the Thirty Years War in Europe and enshrined in the Versailles Treaty of 1948. Opponents of this system directly say that "territorial instincts of territorial states" (Jean-François Richard) [9], "the idea of equal sovereignty of states" (Michael Glennon)[10], that "the main principles of the Westphalian formation, including noninterference in internal affairs, interfere with effective global governance immoral and obsolete "(Henry Kissinger) [11].

Some scholars note that world politics for centuries was an interstate policy, despite the presence of international nongovernmental organizations in the 19th century (for example, the International Telegraph Union, the International Postal Union). However, its active subjects in the second half of the 20th century are transnational corporations, international private financial institutions, non-governmental public organizations, to which states today transfer the exercise of part of their powers. But only a certain part of them, at the same time, the national state has not been canceled. Moreover, paragraph 2 of Article 2 of Chapter I of the Charter of the United Nations proclaims the principle of non-interference in the internal competence of any state [12].

Therefore, the community of experts in the field of international law does not have the right to ignore the trend of erosion of state sovereignty in the face of the proliferation of nuclear weapons in the world, the terrorist threat, the imposition of a policy of US global expansion. Moreover, the conceptual documents of the new National Security Strategy 2017 and the National Defense Strategy - 2018 were developed according to the "America Above All” principle [13].

Therefore, the community of experts in the field of international law does not have the right to ignore the trend of erosion of state sovereignty in the face of the proliferation of nuclear weapons in the world, the terrorist threat, the imposition of a policy of US global expansion. Moreover, the conceptual documents of the new National Security Strategy 2017 and the National Defense Strategy - 2018 were developed according to the "America Above All" principle. The last document unequivocally points out that the main challenge to the prosperity and security of the United States is the "revival of long-term strategic competition" by the "revisionist powers", as Russia and China are called, their "revisionism" is that, rejecting global US hegemony, they seek to "form a world corresponding to their authoritarian model." [14] Therefore, the main task of the United States is "to contain the war, and if it does not work out - to win," in order to maintain world leadership.

The last document unequivocally points out that the main challenge to the prosperity and security of the United States is the "revival of long-term strategic competition" by the "revisionist powers", as Russia and China are called, their "revisionism" is that, rejecting global US hegemony, they seek to "form a world corresponding to their authoritarian model." Therefore, the main task of the United States is "to contain the war, and if it does not work out - to win," in order to maintain world leadership.

The loss of US global leadership, according to Richard Haas, President of the Council on Foreign Relations, threatens a non-polar disorder. He explains this by the fact that, outside of global governance, many flows begin to cross state borders without any control. The same streams often extend the capabilities of non-state actors, such as terrorists, who use the Internet for recruitment and training, the international banking system for transferring funds and the international transport system for moving people; they use the largest corporations that can quickly transfer personnel and investments. If you let it go, the world will become chaotic. Alliances will lose their significance in many respects, since they require predictable threats, clear forecasts and obligations. Relationships will be more selective and situational character [15].

All this is true, but one wonders why, under these conditions, the United States should remain the center of concentration of global influence, when the number of countries that do not agree with US policy based on political pressure and interference in the internal affairs of other states is growing?

In a situation of turbulence of the existing world order, Russia, relying on the constitutional principles of following international law, primarily in the field of preserving and strengthening state sovereignty, respecting the sovereignty of others, defends the multipolar model of the modern world, which is competitive in nature, but is based on a certain balance of power, legal regulation of the international system and multilateral diplomacy. 
Russia's foreign policy activity is associated with the strengthening of integration interactions with other countries. The priority areas of such interaction are the states of the postSoviet space, where real world players compete with Russia China, the European Union, the USA, Turkey and others.

Thus, the European Union is actively building up the Eastern Partnership policy towards Armenia, Azerbaijan, Belarus, Moldova. Turkey is expanding its presence in Azerbaijan. In just a few years, Central Asian countries have fallen predominantly under Chinese influence. The United States invests heavily in post-Soviet economies, exerting political influence on them through "color revolutions" and the so-called "Soft power".

There are clear attempts to limit the sphere of influence of the Eurasian Union (EAEU). The question of the unification of the Caspian and Black Seas is being actively debated. We are talking about economic cooperation, joint transport corridors, hubs. Thus, in Uzbekistan, the idea of creating Greater Turkestan is being put forward. In Poland, the concept of the International Maritime Area is reanimated, which previously set itself the task of creating a confederation from the Baltic to the Black Sea, and today it is proposed to form the BalticBlack Sea region of economic cooperation, of course, without Russia's participation. The European Union has set a goal to form a special, "neighboring region" on its eastern borders, in fact, economically integrated with the EU periphery. This takes into account the experience of the countries of the Visegrad Group (Poland, Hungary, the Czech Republic, Slovakia) and the Central European Free Trade Agreement (CEFTA).

As part of the Eastern Partnership policy, the European Union launched mechanisms for multilateral economic cooperation and regional integration through the participation of partner countries in "thematic platforms" - in the development of small and medium-sized businesses, in the fields of energy, transport and transit, etc. about the free trade zone and association with the EU are in Armenia, Ukraine, Moldova, Georgia. It is obvious that the real goal of the European Union project in the post-Soviet space is related to pushing Russia away, gaining access to the resources of Central Asia, which creates apparent risks for the integration efforts of Russia in the Eurasian space. The EU is trying to use the contradictions within the EAEU for their own purposes. The European Union actively torpedoes the negotiation process of some European countries on a free trade zone with the EEU (for example, Serbia). It should be noted that the new independent states try to pursue a multi-vector policy in order to be less dependent on Russia, and in some cases to be able to manipulate it in their own interests.

Thus, the EAEU is going through a difficult period when the object of competition with other integration projects is not the involvement of certain third countries, but the sustainability and effectiveness of the Eurasian integration project itself, which many external players are not interested in strengthening.

Of course, the Ukrainian direction of Russian foreign policy remains extremely relevant. Ukraine, not coping with its internal problems, focusing on the West, launched an incredible confrontation with Russia. This policy is encouraged by the United States and Western European countries, the EU.
The territory of Ukraine has geopolitical value for them and judging by the nature and focus of Ukrainian foreign policy, regardless of the formal membership in NATO, Ukraine may well expand the American military presence on its territory. As is known, military maneuvers are constantly being held at the Yavorovsky training ground, in which several thousand NATO troops are involved, half of them are Americans. According to Fyodor Lukyanov's figurative expression "The impasse, which Ukraine entered in the construction of modern statehood, is a dead end so hopeless that among the“ advanced "(read ruling) class there was a steady request for external management from the so-called. "Civilized world" [16].

For Russia, the process of resolving the Russian crisis and normalizing relations with Ukraine is a priority task. We are known to be bound by fraternal bonds, whose history is in the centuries. We have a common border, the length of which is $2250 \mathrm{~km}$, of which land - $1925.8 \mathrm{~km}$ (land - $1.500 .2 \mathrm{~km}$, river $422.2 \mathrm{~km}$, lake - $3.4 \mathrm{~km}$ ) and sea - $320 \mathrm{~km}$ (passes through the water area Azov and Black Seas). After the entry of the Republic of Crimea and Sevastopol into Russia, another $8 \mathrm{~km}$ of the Crimean land border can be added to this distance, which runs along the Perekop isthmus. Belgorod, Bryansk, Voronezh, Kursk, Rostov regions and the Republic of Crimea border Ukraine. Border control from the Russian side is carried out at 62 checkpoints (these are 37 roads, 15 railways, 7 airs and 3 seas). Currently, there is a problem of demarcation of the existing border [17].

Unfortunately, it should be agreed with the experts that Russia has not yet developed a comprehensive concept of settling relations with Ukraine [18]. Since the early 1990s. Russia was guided in the Ukrainian field by the need to solve operational tasks and, as a result, did not achieve long-term geopolitical and economic goals.

It is clear that the effectiveness of efforts in foreign policy is largely derived from competent situational and long-term forecasting. Firstly, it makes it possible to identify the leading trends in the development of foreign policy problems and the threats and challenges arising from them. Secondly, the situational forecast allows foreseeing the folding of new situations in order to form an adequate policy. Thirdly, such forecasting makes it possible to assess the resources of the foreign policy influence of all the actors involved.

This is very important in the Arctic region, where the interests of the Arctic countries and new players - non-Arctic states - intersect. For example, the UK has an unbiased, persistent interest in security issues in the Arctic. India, Singapore, Switzerland created their own polar institutions. Switzerland launched its circular Arctic expedition to study extreme climatic conditions, ice changes and possibilities to strengthen it. The European Union is implementing the concept of "New North" and the initiative called "Arctic Window". China proposes the creation of the Arctic belt of the Northern Silk Road. South Korea in 2012 adopted a program to expand its presence in the Arctic. She is even ready to provide support to the indigenous peoples, although it would be nice to consult with the country where these people live. Japan uses cooperation in the Arctic to solve the problems of the northern 
territories. More than 20 scientific conferences are held annually in the Arctic.

In other words, there is a serious struggle for influence in the Arctic region. Some states propose to consider it as the common heritage of mankind, insist on the status of internationalization of the type of the Antarctic, lobbying the transfer under international control of the Russian northern sea route.

All this is not by chance. Indeed, in the Arctic, according to some data, untold riches are concentrated $(30 \%$ of world reserves of natural gas, $13 \%$ of oil, a third of world reserves of fresh water, not to mention minerals). The geopolitical rivalry in the region is indicated by the deployed US military satellite grouping, the military presence and NATO exercises, Norway's attempts to change the status of the Spitsbergen archipelago as a demilitarized zone.

And we are already starting to give adequate answers, because the Arctic sector accounts for $42 \%$ of the Arctic territory. We have a State Commission for the Development of the Arctic. Formed a portfolio of projects (there are more than 150). These are geological exploration, energy, ecology, transport infrastructure, the opening of new ports, the creation of new-generation icebreakers capable of opening the entire northern sea route, border security, etc.). We also provide military security on our territory in the Arctic.

As we can see, today a significant number of countries, even located far from the Arctic region, are interested in its development. Undoubtedly, Russia needs to solve the task of developing the Arctic and developing the Northern Sea Corridor. The Northern Sea Corridor is the shortest way from Asia to Europe and back. For example, if you take an alternative route from the Japanese port of Yokohama to the Dutch port of Rotterdam, the distance between them will be 11,205 miles. And along the Northern Sea Corridor, it will be 3,860 miles shorter. Thus, reducing the time spent on transportation of goods will be 11-12 days. In the development of the Northern Sea Corridor, experts assign the key role to the port of Petropavlovsk-Kamchatsky, which is caused by the presence of the non-freezing Avacha Bay, which allows storing and sorting cargo at any time of the year. It should be noted that the Northern Maritime Corridor is not just a freight route between Vladivostok and Murmansk, but a huge region, the infrastructure of which has great prospects and needs largescale investments.

But we need a full-fledged regulatory legal framework governing the presence of subjects of international relations in the region. It is necessary to improve measures to strengthen regional security, protect the border, and block initiatives to revise the status of the northern sea route. Coordinated coordination of actions of federal executive authorities is required (at the moment, about 20 ministries and departments deal with the problems of the Arctic, but there is no competent authority). It would be necessary to increase the influence of state authorities of the constituent entities of the Russian Federation located in the Arctic zone, to increase control over the expenditure of state funds for the development of the Arctic (which is 5 trillion rubles until 2030).
Russia needs to strengthen bilateral and regional cooperation, be active in the Arctic Council, and assist in giving it the status of a full-fledged international organization. And a permanent situational, strategic forecast will help find the necessary interaction mechanisms, taking into account the approaches to international cooperation in the region specified in the Foreign Policy Concept.

The objective possibility of leveling the negative political and economic consequences of the current international antiRussian sanctions by Western countries actualizes the theme of the development of international economic relations of the Far Eastern subjects of the Russian Federation with the countries of the Asia-Pacific region, especially with the countries of NorthEast Asia. The least alarming and most promising from the point of view of establishing long-term international economic relations can be considered the direction of the countries of Northeast Asia, and in particular the "Chinese" one, the PRC is the most important and promising foreign policy partner for Russia. The reason for good-neighborly relations between Russia and the PRC lies both in the conflict-free historical experience of interstate relations, and in the very nature and traditions of both peoples [19].

The Far Eastern Federal District of the Russian Federation is the most promising entity in the development of sustainable international economic relations with the APR countries, which continues to interest foreign partners from the APR countries, who pragmatically put the interests of long-term economic development at the center, rather than their geopolitical ambitions.

In the near historical perspective, the national interests of the leading states will continue to concentrate on the control of territories with mineral-raw and fuel-energy resources, as well as on gaining access to territories with high environmental quality. The main instrument for the protection of the national interests of the Russian Federation is an active foreign policy. Its implementation contributes to the implementation of successful economic transformations, enhancing the place and role of Russia in the international arena, preserving international stability in general.

The geopolitical role of the Russian Far East in the development of international economic relations with the countries of the Asia-Pacific region is enormous, due to the presence of significant, even on a global scale, mineral and raw materials, fuel and energy, forest and marine biological resources. In the depths of the Far East and Transbaikalia, 30\% of Russian reserves of coal, $20 \%$ of hydrocarbons, $25 \%$ of wood, $80 \%$ of diamonds are concentrated, and there are significant reserves of rare-earth and non-ferrous metals. It contains reserves of about 23 million tons of copper, 2 million tons of tin, more than 6.5 thousand tons of gold, over 500 thousand tons of natural uranium reserves. In the Far Eastern territories located in close proximity to the fast-growing economy of China, over $90 \%$ of Russian reserves of platinum metals are concentrated [20].

The strength and prospects for the development of RussianChinese relations are also noted by researchers from the United States. For example, Evan S. Mederios and Michael S. Chase believe that a reliable basis for the development of Chinese- 
Russian cooperation for the next ( 0 -3 years) and medium-term (3-5 years) perspective is justified for China by the following factors: opposition to hegemony USA; US opposition to the spread of democracy and subversion; countering US defense policies that undermine strategic stability in the Asia-Pacific region; countering US policy in space and cyberspace; access to Russian military equipment and advanced defense technologies; strong trade and investment ties with Russia; the ability to gain access to Russian energy [21].

In 2013, PRC Chairman Xi Jinping launched an important initiative to build the "Silk Road Economic Belt" and "The 21st Century Silk Road” (“One Belt and One Road”), which attracted great attention of the world community. In order to implement the concept of "One Belt and One Road" as soon as possible, China is ready to cooperate with Russia in most infrastructure projects in the Russian Far East, including oil and gas pipelines, cross-border bridges, sea and continental logistics, in the construction of territories of advanced social and economic development, confrontation floods and disaster management, calculation in national currencies [22]. Russia, in turn, proposes to implement the Chinese project "One Belt and One Road" through its "conjugation" with the Eurasian Economic Union (EAEU) and the Shanghai Cooperation Organization (SCO) [23]. In our opinion, the pairing of the Chinese initiative with the development of the Northern Sea Corridor is particularly interesting for Russia.

A promising direction in the development of international relations, on which Russia is currently focusing its efforts, is the development of interstate cooperation with Japan, through the achievement of progress on the "northern territories" and the signing of a peace treaty after the end of World War II.

For a long period of time, the Japanese authorities and the expert community have linked the development of international economic cooperation with Russia with the resolution of a territorial dispute over the disputed "northern territories" - the southern islands of the Kuril chain. Thus, in his studies, Professor of the Center for Slavic Studies at Hokkaido University Akihiro Iwasita, noting the enormous potential for the development of Russian-Japanese international economic relations, suggests that the interest of the Japanese side in developing cooperation between the two countries will directly depend on the resolution of the issue of transferring controversial to Japan "Northern territories" [24]. Representatives of the Japanese authorities also adhere to this point of view, at the highest level trying to resolve the issue of the "northern territories", for example, on May 6, 2016 at the meeting of President of the Russian Federation V.V. Putin's Prime Minister Shinzo Abe proposed a cooperation plan aimed at a possible solution to the problem of the "northern territories”.

The search for a compromise solution around the "northern territories" has now been significantly intensified. RussianJapanese summit talks are held on an ongoing basis in Moscow and Tokyo. [25]. However, according to our assessment, the existing agreements only indirectly create a favorable atmosphere for the development of Russian-Japanese relations and are the first step in resolving the territorial problem between Japan and Russia.
The Eastern vector of modern Russian foreign policy to a large extent allows Russia to remain among the key players in the international political arena, allows finding points of contact between Russian interests and the interests of countries such as the PRC and Japan, which also actively influence the international political environment.

Weighted valuation approaches require the entire set of national interests of Russia, embodied in foreign policy activities that implement the foreign policy function of the Basic Law.

Thus, a dynamically changing world, its challenges and threats (new forms of terrorism, the proliferation of weapons of mass destruction, transnational criminal networks, drug business, armed conflicts (real and potential), etc.) involve the development of effective political and legal tools for global cooperation to avoid problems constitutional security of the state.

Increased attention from the political leadership of Russia requires, in our opinion, US attempts to impose a so-called American model of democracy on a number of sovereign states of the world. Its essence is to establish, in a country that has fallen into the zone of American interests, a regime acceptable to the American administration. To implement these imperial plans, the US leadership used not only political, military, but also economic leverage. Today, the US economy makes up a quarter of the global gross product and makes it possible to economically ensure the promotion of the "American democracy" model in the world.

The practice of Washington is widely known to use the US and its allies in military-political blocs to promote the American model of democracy. The uncovered US military aggression against Yugoslavia, a sovereign European state, can be considered a kind of guideline in the spring of 1999, after which the US openly ceased to reckon with the norms of international law. After the bombing of the territory of the Federal Republic of Yugoslavia on March 24, 1999, by NATO aircraft and rocket attacks on objects on the Montenegrin coast of the Adriatic Sea, the American media reported that NATO was "fighting for democracy in the Balkans" [26]. The damage caused to industrial, transport and civilian facilities of the Federal Republic of Yugoslavia as a result of almost threemonth bombardments, according to various estimates, are estimated at between 60 and 100 billion dollars. The death toll of military and civilians has not yet been precisely determined. It varies from 1200 to 2500 people; including 800 children were killed [27].

On March 20, 2003, the United States, together with the United Kingdom, without the sanction of the UN Security Council, launched a military campaign against Iraq. Under the pretext that Iraq has weapons of mass destruction (which, by the way, was not found), as well as a hypothetical link between Saddam Hussein's regime and Al-Qaeda fabricated by Washington itself. As additional justifications Washington called "violations of democracy" and repression by the Iraqi authorities against their citizens. During the Iraq war, about 4,500 American servicemen were killed and more than 32,000 were injured, and up to 1.5 million civilians were injured. At 
present, Iraq remains the main source of instability in the Middle East.

2011, Libya. As a result of the "soft power" campaign organized by the White House to internationally condemn the Gaddafi regime; in March 2011 five American bombers dropped bombs for almost a hundred targets in Libya. In October 2011, the rebels (allegedly with the help of the Americans) tracked down the Libyan dictator, captured him and shot him without trial and investigation, after having been tortured.

To support democratic movements in other countries and promote the idea of liberal democracy in the image and likeness of the United States, American politicians created a number of political tools: the US Agency for International Development (USAID), Peace Corps, Union for Progress, Radio Free Europe , "National Democracy Fund", etc.

US politicians have come up with a political tool called "American democracy," and apply where there is a smell of oil, other natural resources that can be profit by changing the political regime in a particular country through controlled social chaos or other modern political technologies [26]. This conclusion is convincingly confirmed by the "color" revolutions: 2003 - the "rose revolution" in Georgia, 2004 - the "orange revolution" in Ukraine, 2005 - the "tulip revolution" in Kyrgyzstan, 2014 - Euromaidan and the coup d'état in Ukraine, and also current events in Venezuela.

Russia chose troubled Venezuela as its ally in Latin America. A bit of history, until 2009, relations between Russia and Venezuela were completely normal and civilized, and developed on a mutually beneficial basis. It was the relationship between the seller of weapons to countries of "non-American" orientation and a new country rich in oil and petrodollars. Former President Hugo Chavez came to Russia, made large orders, paid in dollars - and it was beneficial for all and quite understandable from the point of view of national interests. But starting in 2009, Venezuela began to buy Russian weapons not for cash, but on credit, taking advantage of the fact that the Russian Federation often lends to its arms buyers. By 2019, according to official data, the public debt of Caracas to Moscow exceeded \$ 3 billion. It was restructured, and the first payments were postponed to the first half of the 2020s, since Venezuela now has nothing to pay. Moreover, given the situation that we see in the Venezuelan economy, Venezuela will not soon begin to repay this loan. And this risk, by the way, arose long before the United States began helping with the organization of the coup d'état [28].

Despite the fact that President Nicolas Maduro proved to be not a very inept manager and inefficient manager who brought the country to abject poverty and even famine, Russia did not withdraw its assets from the troubled country, because friendship with it promised our country billions in profits. In pursuit of profit, a consortium of 5 Russian oil companies, including the state-owned corporation Rosneft, has already invested \$ 17 billion in the declining economy of Venezuela. Instead of investing in the socio-economic development of Siberia, raising Rosneft continues to help troubled Venezuela, while Russian media provide information support to Maduro. Russian capitalists decided to extract oil in Venezuela. But oil in this country is heavy, and in order to process it, you need to build a separate plant, an upgrader, the price of which is several billion dollars. In addition, in order to add light fractions to the heavy Venezuelan oil and only after that to transport it through the pipeline, it is necessary to buy American oil. Our oil bosses didn't do timely technological expertise and with great delay paid money to foreign oilfield services companies.

Meanwhile, political processes took place in Venezuela, to which greedy and short-sighted Russian capitalists paid little attention: Nicolas Maduro gradually lost control over the problematic country in which hyperinflation was developing. If in 2016 it exceeded 500\% per year, then according to the International Monetary Fund (IMF), the rate of inflation in Venezuela at the beginning of 2019 will reach 1,000,000\% inflation. [29]. This indicates that the situation in Venezuela is similar to that in Germany in 1923 or in Zimbabwe in the late 2000s. It is characterized by a fall in GDP, hyperinflation and a further deterioration in the standard of living of the population, which together cause widespread dissatisfaction of citizens with the ruling regime. The catalyst for the growth of hyperinflation in the country was the US economic sanctions imposed in January 2019 against the Venezuelan Oil Company.

Thus, Venezuela is in a "deep economic and social crisis. Under increasing US political and economic pressure, elected President Nicolas Maduro has found it increasingly difficult to retain power in the country. Maduro's friends are getting less and less. Already there are reports that the current president formally supports China to negotiate with the opposition [30].

And if the US has noticeable successes in applying political and economic pressure on Venezuela, then sanctions against Russia do not achieve the effect for which they were intended. Of course, anti-Russian sanctions to a certain extent slow down the economic development of the country, but they are not able to influence the change of political regime in the Russian Federation. But the US administration headed by President D. Trump cannot solve this problem by armed attack because of common sense. Russia is not Libya and not Iraq, and V. Putin is not Saddam Hussein. Thanks to the energetic actions of the third president, the Russian Federation has a powerful nuclear missile weapon capable of delivering a crushing retaliatory strike against any aggressor. Nor will the military-strategic parity change the US withdrawal from the treaty on medium and shorter-range missiles, or even attempts to deploy such weapons along the borders of our country. President V. Putin warned supporters of such pressure, delivering another message to the Federal Assembly on February 20, 2019: "Russia will have to create and deploy weapons that can be used not only in respect of those territories from which we will emanate a direct threat but also in respect of the territories where decision-making centers are located on the use of rocket complexes threatening us” [31].

\section{PuRPOSE OF THE STUDY}

The aim of the study is to study the problems that Russia faces in carrying out foreign policy activities, which is especially important in the context of Western sanctions.

\section{RESEARCH QUESTIONS}

In this study addresses the following issues. 
1. The authors consider the problems of the implementation of Russian foreign policy with the intervention of the United States.

2. The authors also studied issues related to the export of the American model of democracy.

3. A special place in the study is given to the difficulties of the implementation of Russia's foreign policy activities in the context of Western sanctions.

The methodological basis of the publication consists of the following methods: the structural and functional method, the construction of the political and social model, the scenario approach and the scenario projection method, the method of analysis of political texts.

\section{FINDINGS AND CONCLUSION}

Conflict with Western countries in the international arena after the annexation of Crimea to Russia and the events in the south-east of Ukraine is becoming increasingly serious; therefore, the international policy of Russia today is greatly affected by confrontation with the United States and tensions with the EU states. Western sanctions imposed in response to Moscow's actions against Ukraine exacerbated the already difficult international situation, forcing Russia to respond in foreign policy.

At the moment, Moscow faces difficult foreign policy tasks: to withstand sanctions pressure from the United States and its allies, reduce political isolation, adapt the economy to sanctions and confront the West in the information space.

Russia's main foreign policy priorities are to block the further expansion of NATO in Eastern Europe and to confirm its status as a great power outside the post-Soviet space. In this regard, one of the main directions of the foreign policy activities of the Russian Federation is, in our conviction, that the United States and its satellites are forced to recognize Russia's security interests, to be considered on the world stage.

Due to the deterioration of relations with Western countries, the importance of relations with other partners in Russia's foreign policy activities has increased. One of the main activities here is to increase the productivity of relations with China, a growing world power with a powerful economy, an order of magnitude superior to our country, which has not joined the anti-Russian sanctions. However, the RussianChinese friendship has its limitations. China does not want to spoil business relations with the United States, and Russia is trying not to become dependent on an economically stronger partner. In addition, the interests and strategy of the two countries do not always coincide. Thus, the main priorities in this direction are to strengthen ties with China and preserve the friendly nature of bilateral relations with Beijing.

On all major issues of foreign policy, defense and security, President V.V. Putin He has been the national leader of Russia since 2000 and one of the most experienced political leaders in the world. Putin has absolute power, based on unprecedented and constant popularity among ordinary Russians. A foreign policy aimed at returning Russia to the status of a great power is one of the most important reasons for this popularity.
And the achievement of ambitious goals and the implementation of strategic objectives in socio-economic development, defined in his decree of May 7, 2018, will strengthen the position of the Russian Federation and its president in the international arena, despite the anti-Russian sanctions.

\section{REFERENCES}

[1] The Constitution of the Russian Federation (adopted by popular vote on 12.12.1993) (as amended by laws of December 30, 2008 No. 6-FKZ, of December 30, 2008 No. 7-FKZ, of February 5, 2014 No. 2-FKZ, of July 21, 2014 N 11-FKZ). - Retrieved from: http://www.consultant.ru/ document/cons_doc_LAW 28399.

[2] Presidential Decree of 30.11.2016 N 640 "On approval of the Concept of the foreign policy of the Russian Federation". - Retrieved from: //http: //www.consultant.ru/document/cons_doc_LAW_207990/5a8fbcac394dd ab0776787a083406b2583bd2bdc/.

[3] Presidential Decree of 31.12.2015 N 683 "On the Strategy of the National Security of the Russian Federation". - Retrieved from: http://www.consultant.ru/document/cons_doc_LAW_191669/61a97f7ab 0f2f3757fe034d11011c763bc2e593f/.

[4] Military doctrine of the Russian Federation. Approved By the President of the Russian Federation on 12/25/2014 N Pr-2976. - Retrieved from: kremlin.ru/media/events/files/41d527556bec8deb3530.

[5] Maritime Doctrine of the Russian Federation. Approved by the President of the Russian Federation 07.26.2015). - Retrieved from: http://www.consultant.ru/document/cons_doc_LAW_208427.

[6] Presidential Decree of 05.12.2016 N 646 "On approval of the Information Security Doctrine of the Russian Federation". - Retrieved from: //http://www.consultant.ru/document/cons_doc_LAW_208191/ 4dbff9722e14f63a309bce4c2ad3d12cc2e85f10/.

[7] Presidential Decree of 06.05.2011 N 590 (ed. 07.25.2014) "Questions of the Security Council of the Russian Federation" (along with the "Regulations on the Security Council of the Russian Federation", "Regulations on the Security Council of the Russian Federation". Retrieved from: http://www.consultant.ru/document/cons_doc_LAW_ 113807/382ed8c05e1f30948371b804df610806c900f6af/.

[8] United States National Military Strategy. - Retrieved from: https://inosmi.ru/op_ed/20150703/228922858.html.

[9] Twenty years later. Global problems and ways to solve them // Russia in global politics, vol. 2, p. 164.

[10] M. Glennon. Security Council: what is the reason for the collapse?// Russia in global politics, 2003, vol. 3, pp. 118 - 120.

[11] G. Kissinger. The World Order p. 32. Retrieved from: https: //bookz.ru/ authors/genri-kissindjer/mirovoi-_640/page-7-mirovoi-_640.html.

[12] Charter of the United Nations (Adopted in San Francisco 06.26.1945) // - Retrieved from: http://www.consultant.ru/document/cons_doc_LAW_ $121087 /$.

[13] The United States has included Russia in the list of threats to national security. - Retrieved from: https://rg.ru/2018/01/19/ssha-vkliuchilirossiiu-v-spisok-ugroz-nacionalnoj-bezopasnosti.html.

[14] N. Bobkin., The US National Defense Strategy in the Conditions of the Disappearance of the Global Leader. - Retrieved from: http://geopolitica.info/nikolay-bobkin-strategiya-natsionalnoy-oborony-ssha-vusloviyakh-ischeznoveniya-globalnogo-lidera.html.

[15] Richard H. Epoch of the non-polar world // Russia in global politics, 2008, vol. 4. - Retrieved from: https://globalaffairs.ru/number/n_11144.

[16] F. Lukyanov. The Ukrainian Question for the Future of Russia. Retrieved from: https: //globalaffairs.ru/number/Ukrainskii-vopros-dlyabuduschego-Rossii-19532.

[17] Russian-Ukrainian border. Dossier. Retrieved from: https://tass.ru/info/ 1267817.

[18] A. Gushchin. The evolution of the post-Soviet space: past, present, future. M., 2016; Lukyanov F. Russia's Foreign Policy in 2018: More Problems than Success. - Retrieved from: http://russiancouncil.ru/ 
analytics-and-comments/comments/vneshnyaya-politika-rossii-v-2018godu-problem-bolshe-chem -uspekhov /? sphrase_id = 23690401.

[19] A.S. Sidorov Strategic priorities of Russian foreign policy in the APR // Observer-Observer. 2016, vol. 9 (320), pp. 46-56.

[20] M. Titarenko. Russia and China: Strategic Partnership and the Challenges of Time. M., 2014, p. 75.

[21] S. Evan Medeiros and Michael S. Chase "Chinese Perspectives on the Sino-Russian Relationship". // National Bureau of Asian Research. NBR special report , vol. 66, july 2017, pp 1-12.

[22] Su Fanqiu. Excellent prospects for cooperation // Russia and the APR. Vladivostok, 2015, vol. 3, pp. 253-254.

[23] S.G. Luzyanin, N.M. Semenova. Russia - China - Central Asia: transport and energy interests // “Observer - Observer”, Moscow, 2016, vol. 2 (313), p. 59.

[24] A. Iwashita, "An Inquiry for the Sino-English Negotiations”; A.Iwashita (ed.), Siberia and the Russian Far East in the 21st Century: Partners in the "Community of Asia", vol. 1, Crossroads in Northeast Asia, Sapporo, 2005; A. Iwashita, ed., Eager Eyes, Slavic Eurasian Studies, vol. 16-2 (Sapporo: SRC, 2007) (in English)
[25] Kaoru Yokibe Japan and Russia: an interpretation of history and a territorial problem. // Carnegie Moscow Center, 2016, 27p.

[26] V.F. Nirtsevich, V.V Moiseev, O. A. Sudorgin. Managed social chaos as the technology of export of liberal democracy. European Proceedings of Social and Behavioural Sciences, 2017, vol. XXXV (35), pp. 979-991.

[27] Destruction of Yugoslavia: a history of conflict.. - Retrieved from: http://www.srpska.ru/article.php? nid = 11087 .

[28] "Why does Russia invest money in Venezuela, but not in Siberia?" Retrieved from: https://news.mail.ru/politics/36419057/?frommail=1.

[29] IMF: inflation in Venezuela will reach $1,000,000 \%$ by the end of the year. - Retrieved from: https://tass.ru/ekonomika/5396991.

[30] Nicolas Maduro is a loser and a problem ally. But friendship with him promises billions. - Retrieved from: https://news.rambler.ru/politics/ $41775463 /$ ? utm_ content $=$ rnews \& utm_medium = read_more \& utm_source $=$ copylink.

[31] President's Message to the Federal Assembly. - Retrieved from: http://kremlin.ru/events/president/news/59863. 